\title{
Effect of different curd-washing methods on the insoluble Ca content and rheological properties of Colby cheese during ripening
}

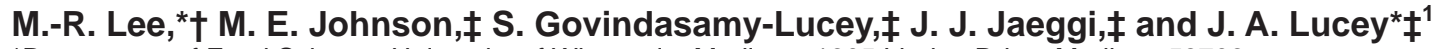 \\ *Department of Food Science, University of Wisconsin-Madison, 1605 Linden Drive, Madison 53706 \\ †Department of Animal Bioscience, Institute of Agriculture and Life Science, Gyeongsang National University, Jinju 660-701, South Korea \\ ¥Wisconsin Center for Dairy Research, University of Wisconsin-Madison, 1605 Linden Drive, Madison 53706
}

\section{ABSTRACT}

A curd-washing step is used in the manufacture of Colby cheese to decrease the residual lactose content and, thereby, decrease the potential formation of excessive levels of lactic acid. The objective of this study was to investigate the effect of different washing methods on the Ca equilibrium and rheological properties of Colby cheese. Four different methods of curd-washing were performed. One method was batch washing (BW), where cold water $\left(10^{\circ} \mathrm{C}\right)$ was added to the vat, with and without stirring, where curds were in contact with cold water for $5 \mathrm{~min}$. The other method used was continuous washing $(\mathrm{CW})$, with or without stirring, where curds were rinsed with continuously running cold water for approximately $7 \mathrm{~min}$ and water was allowed to drain immediately. Both methods used a similar volume of water. The manufacturing $\mathrm{pH}$ values were similar in all 4 treatments. The insoluble (INSOL) Ca content of cheese was measured by juice and acid-base titration methods and the rheological properties were measured by small amplitude oscillatory rheology. The levels of lactose in cheese at $1 \mathrm{~d}$ were significantly higher in $\mathrm{CW}$ cheese $(0.06-0.11 \%)$ than in BW cheeses $(\sim 0.02 \%)$. The levels of lactic acid at 2 and 12 wk were significantly higher in CW cheese than in BW cheeses. No differences in the total $\mathrm{Ca}$ content of cheeses were found. Cheese $\mathrm{pH}$ increased during ripening from approximately 5.1 to approximately 5.4. A decrease in INSOL Ca content of all cheeses during ripening occurred, although a steady increase in $\mathrm{pH}$ took place. The initial INSOL $\mathrm{Ca}$ content as a percent of total $\mathrm{Ca}$ in cheese ranged from 75 to $78 \%$ in all cheeses. The INSOL Ca content of cheese was significantly affected by washing method. Stirring during manufacturing did not have a significant effect on the INSOL Ca content of cheese during ripening. Batch-washed cheeses had significantly higher INSOL Ca contents than did CW cheeses during the first $4 \mathrm{wk}$ of ripening. The maximum loss tangent val-

Received August 23, 2010.

Accepted February 19, 2011.

${ }^{1}$ Corresponding author: jalucey@facstaff.wisc.edu ues (meltability index) of CW cheese at $1 \mathrm{~d}$ and $1 \mathrm{wk}$ were significantly higher compared with those of BW cheeses. In conclusion, different curd washing methods have a significant effect on the levels of lactose, lactic acid, meltability, and INSOL Ca content of Colby cheese during ripening.

Key words: insoluble $\mathrm{Ca}$, curd washing, cheese rheology, meltability

\section{INTRODUCTION}

Curd washing or dilution of whey with water is used in the manufacture of Colby, Monterey, and Goudatype cheeses (Fox and McSweeney, 2004). In Colby cheese making, curd washing was originally introduced to help produce high moisture (39-40\%), reduced acid, and open-textured cheese (Wilson and Reinbold, 1965). During Colby cheese making, cold water is added after whey drainage and the curd is held for 5 to $20 \mathrm{~min}$ in the water/whey mixture with continuous agitation to help achieve a uniform temperature (Van Slyke and Price, 1936).

Various types of curd-washing approaches are performed in the cheese industry, depending on the targeted properties of cheese, and these include varying the time that the curd is being held in wash water, the amount of water added and the temperature of wash water.

Including a washing step during cheese manufacturing can affect the yield (higher moisture) as well as the chemical composition, such as residual lactose, lactic acid, and pH (Van den Berg and De Vries, 1974; Lolkema, 1994; Walstra et al., 1999; Fox and McSweeney, 2004). In Gouda-type cheese making, after approximately 25 to $45 \%$ of the whey is drained, warm water $\left(35^{\circ} \mathrm{C}\right)$ is added. Warm water enhances syneresis and some lactose is removed. After the wash water is added, the lactose content in curd decreases with only a slight increase in the lactic acid of the curd (Fox and McSweeney, 2004). Lolkema (1994) pointed out that to decrease the risk of producing an acid Gouda cheese, the use of correct quantities of wash water was critical; he suggested that the required amount of wash water 
should be selected based on the composition of the cheese milk. He also suggested that the $\mathrm{pH}$, composition (e.g., moisture and lactic acid), and yield of cheese can be determined by the quantity of wash water used. He demonstrated that as the amount of wash water increased from 0 to $70 \%$ (as a percentage of curd after the first drain), the yield of cheese decreased from 11.2 to $10.7 \mathrm{~kg}$ of cheese $/ 100 \mathrm{~kg}$ of milk. Also, the moisture content of Gouda cheese varied from 34.7 to $50 \%$ when the amount of wash water (as a percentage of curd after the first drain) was increased from 0 to approximately $76 \%$; the amount of lactose and protein in second whey of Gouda cheese decreased from 5.1 to $2.8 \%$ and 0.8 to $0.4 \%$, respectively, as the amount of wash water increased from 0 to $70 \%$ (Lolkema, 1994).

Van den Berg and De Vries (1974) also showed that to make Gouda cheeses with similar $\mathrm{pH}$ and moisture content, only $20 \mathrm{~kg}$ of water per $100 \mathrm{~kg}$ of whey + curd mixture was needed when the lactose content of cheese milk was $4.3 \%$, whereas $33 \mathrm{~kg}$ of water per $100 \mathrm{~kg}$ of whey + curd mixture was required when the lactose content of cheese milk was $4.7 \%$. They also proposed that the wash effect depends on the timespan between the addition of curd wash water and the holding time of curd in wash water.

Several studies have been done to determine changes in the chemical properties of cheese during ripening when curd washing or whey replacement was used (Huffman and Kristoffersen, 1984; Shakeel-Ur-Rehman et al., 2004). Huffman and Kristoffersen (1984) varied the lactose content in curd by the addition of lactose to the whey or replacement of one-half of the whey with buffer during cheese making. Huffman and Kristoffersen (1984) varied the lactose content in cheese at $1 \mathrm{~d}$ from 0.1 to $0.4 \%$; after 9 mo, lactose in cheese ranged from 0 to $0.2 \%$. Shakeel-Ur-Rehman et al. (2004) varied the residual lactose content in cheese by replacing some part of whey with warm water as well as by the addition of lactose powder. The lactose content of cheese at $1 \mathrm{~d}$ ranged from 0.3 to $2.2 \%$ and the high residual lactose cheese exhibited a significant decrease in cheese $\mathrm{pH}$ (from 5.3 to 4.8) during the 9-mo ripening period.

Lee et al. (2010) investigated the effect of different manufacturing conditions (i.e., varying the lactose content of the milk and $\mathrm{pH}$ values at critical steps in the cheesemaking process) on the insoluble (INSOL) Ca content and rheological properties of Colby cheese during ripening. The washing method used by Lee et al. (2010) was batch washing [BW; i.e., water added after the whey was completely drained (in most of the studies mentioned above, part of the whey was replaced with water or buffer)]. Lee et al. (2010) reported that curd washing significantly decreased the levels of lactic acid produced during ripening and resulted in signifi- cantly higher INSOL Ca content compared with cheese made without curd washing.

Although several previous studies have been done on curd washing, none of the studies previously mentioned investigated the effect of using different washing methods on cheese properties. Two approaches to washing, or soaking, are used by Colby cheese manufacturers: $\mathrm{BW}$ and continuous washing $(\mathbf{C W})$. During $\mathrm{CW}$, the curd is stirred as water is added and allowed to drain immediately. In BW, water is added to the vat and the curd remains in contact with the water. We predicted that the different washing methods could alter the amount of lactose, lactic acid, and soluble Ca remaining in the curd after washing. In Gouda cheese making, about $98 \%$ of the lactose is washed out or lost in the whey, but that is dependent on the duration of washing (contact time), the size of curd grains, and the intensity of stirring (Walstra et al., 1999). The objectives of this study were to investigate the effects of different curd washing methods on the $\mathrm{Ca}$ equilibrium and the functional properties of Colby cheese.

\section{MATERIALS AND METHODS}

\section{Cheese Manufacturing}

Four types of full-fat, washed-curd Colby cheese were manufactured, described as BW with no stirring (BWNS), BW with stirring (BWWS), CW with no stirring (CWNS), and CW with stirring (CWWS). Cheeses were made on 3 occasions by licensed cheese makers at the University of Wisconsin-Madison Dairy Plant. The detailed make-procedure for these cheeses is shown in the Table 1 . Three cheese trials were performed over a 4-mo period. A mixed strain starter culture consisting of Lactococcus lactis ssp. cremoris and Lactococcus lactis ssp. lactis was inoculated into the milk at the rate of $1.490 \mathrm{~g} / 226 \mathrm{~kg}$ of milk (the amount of milk used in the vat was $226 \mathrm{~kg}$ ). This bulk culture had been grown up in skim milk overnight. Double-strength chymosin (Chymax Extra, Chr. Hansen, Inc., Milwaukee, WI) was added at the rate of 17 $\mathrm{mL} / 226 \mathrm{~kg}$ of milk at $32^{\circ} \mathrm{C}$. The coagulum was cut with a $0.63-\mathrm{cm}$ knife and the curd was given a 5 -min healing time before gentle agitation for 10 to $15 \mathrm{~min}$. The curd-whey mixture was heated slowly from 32 to $39^{\circ} \mathrm{C}$ and continuously stirred at $39^{\circ} \mathrm{C}$ until the $\mathrm{pH}$ of curd reached approximately 6.2. For the BW cheeses, after the first draining, approximately $18 \mathrm{~kg}$ of cold water $\left(\sim 10^{\circ} \mathrm{C}\right)$ was added immediately (within a 2 -min period) to the cheese curd. After addition of the cold water, the curd was held (soaked) in cold water for 5 min with or without manual stirring. For the CW cheeses, a similar quantity of cold water was added 
Table 1. Cheesemaking protocols used for Colby cheese manufactured using different washing methods $(\mathrm{n}=$ $3)^{1}$

\begin{tabular}{|c|c|c|c|c|}
\hline \multirow[b]{2}{*}{ Item } & \multicolumn{2}{|c|}{ Without stirring } & \multicolumn{2}{|c|}{ With stirring } \\
\hline & $\begin{array}{l}\text { Total elapsed } \\
\text { time (min) }\end{array}$ & $\mathrm{pH}$ & $\begin{array}{l}\text { Total elapsed } \\
\text { time (min) }\end{array}$ & $\mathrm{pH}$ \\
\hline \multicolumn{5}{|l|}{ Batch washing } \\
\hline Initial milk & 0 & $6.59 \pm 0.01$ & 0 & $6.59 \pm 0.02$ \\
\hline Add starter & 0 & $6.59 \pm 0.01$ & 0 & $6.59 \pm 0.02$ \\
\hline Add coagulant & $60 \pm 0$ & $6.51 \pm 0.01$ & $60 \pm 0$ & $6.51 \pm 0.01$ \\
\hline Cut & $80 \pm 1$ & $6.50 \pm 0.00$ & $80 \pm 1$ & $6.49 \pm 0.01$ \\
\hline First drain & $160 \pm 0$ & $6.05 \pm 0.06$ & $162 \pm 3$ & $6.00 \pm 0.00$ \\
\hline Add water & $203 \pm 10$ & $5.70 \pm 0.00$ & $201 \pm 10$ & $5.70 \pm 0.00$ \\
\hline Second drain & $210 \pm 10$ & $5.65 \pm 0.04$ & $208 \pm 10$ & $5.62 \pm 0.00$ \\
\hline Add salt & $223 \pm 10$ & $5.59 \pm 0.07$ & $222 \pm 12$ & $5.56 \pm 0.04$ \\
\hline \multicolumn{5}{|c|}{ Continuous washing } \\
\hline Initial milk & 0 & $6.58 \pm 0.01$ & 0 & $6.58 \pm 0.01$ \\
\hline Add starter & 0 & $6.58 \pm 0.01$ & 0 & $6.58 \pm 0.01$ \\
\hline Add coagulant & $60 \pm 0$ & $6.51 \pm 0.01$ & $60 \pm 0$ & $6.45 \pm 0.13$ \\
\hline Cut & $80 \pm 1$ & $6.50 \pm 0.03$ & $81 \pm 1$ & $6.48 \pm 0.02$ \\
\hline First drain & $160 \pm 0$ & $5.98 \pm 0.06$ & $160 \pm 0$ & $5.92 \pm 0.06$ \\
\hline Add water & $201 \pm 10$ & $5.70 \pm 0.00$ & $198 \pm 16$ & $5.69 \pm 0.04$ \\
\hline Second drain & $208 \pm 10$ & $5.69 \pm 0.00$ & $207 \pm 14$ & $5.69 \pm 0.00$ \\
\hline Add salt & $222 \pm 12$ & $5.51 \pm 0.07$ & $222 \pm 16$ & $5.53 \pm 0.02$ \\
\hline
\end{tabular}

${ }^{1}$ Values \pm SD.

(sprinkled/sprayed) to the cheese curd with continuous draining (from the vat) for $7 \mathrm{~min}$ with and without manual stirring. After the second drain, curd was salted at the rate of $0.72 \mathrm{~kg} / 226 \mathrm{~kg}$ of milk. Salted curd was packed in 9-kg Wilson-style hoops (Koss Industrial, Inc., Green Bay, WI) and pressed at $276 \mathrm{kPa}$ for $3 \mathrm{~h}$ at ambient temperature. Cheese was kept overnight at ambient temperature before vacuum packaging. After vacuum packaging, the cheese was stored at $6^{\circ} \mathrm{C}$ for further analysis. Two 9-kg blocks of cheese were made from each treatment in each trial.

\section{Compositional Analysis}

All compositional tests were done at least in triplicate. Milk was analyzed for total solids, CN, fat, and protein content (Marshall, 1992). Rennet whey was made from cheese milk on the same cheesemaking day (Lee et al., 2010) and the total Ca content of milk and rennet whey was measured by inductively-coupled argon plasma emission spectroscopy (Park, 2000). Cheese was analyzed for moisture, fat, protein (Marshall, 1992), and salt by a Corning (Medfield, MA) salt analyzer (Marshall, 1992). Lactose and lactic acid (both D- and L-lactate) of milk and cheese were determined by enzymatic methods (Severn et al., 1986; IDF, 1993). During cheese ripening, cheese $\mathrm{pH}$ using a $\mathrm{pH}$ electrode (Sam Gray gold electrode; Nelson-Jameson, Marshfield, WI; Marshall, 1992), pH 4.6-soluble nitrogen (Kuchroo and Fox, 1982), and the INSOL Ca contents of cheese were analyzed (juice and titration methods; Hassan et al.,
2004) at $1 \mathrm{~d}, 1 \mathrm{wk}, 1 \mathrm{mo}$, and 3 mo. The buffering capacity of cheese was determined by acid-base titration (Hassan et al., 2004) and the buffering capacity was reported as volume of $0.5 \mathrm{~N} \mathrm{HCl}$ needed to decrease the $\mathrm{pH}$ of cheese dispersions by $1.0 \mathrm{pH}$ unit from the initial pH of cheese dispersions (Lee et al., 2010).

\section{Dynamic Small Amplitude Oscillatory Rheometry}

The viscoelastic properties of cheese were determined by a Paar Physica universal dynamic spectrometer (UDS 200; Physica Messtechnik, Stuttgart, Germany) using dynamic small amplitude oscillatory rheology (SAOR). The procedure described by Lucey et al. (2005) was used. The viscoelastic properties were measured at an applied strain of $0.2 \%$. Cheeses were heated from 5 to $80^{\circ} \mathrm{C}$ at the rate of $1^{\circ} \mathrm{C} / \mathrm{min}$. The rheological parameters, including storage modulus $\left(\mathbf{G}^{\prime}\right)$, or stiffness; loss modulus $\left(\mathbf{G}^{\prime \prime}\right)$; and loss tangent (LT), which is the ratio between the viscous and the elastic properties of the material $\left(\mathrm{LT}=\mathrm{G}^{\prime \prime} / \mathrm{G}^{\prime}\right)$, were determined from SAOR tests. At least 3 replicates were measured for each cheese sample at each ripening time point.

\section{Statistical Analysis}

Data was analyzed using the statistical analysis system, version 8.02 (SAS Institute Inc., Cary, NC). Experimental effects of different curd washing method (BWNS, BWWS, CWNS, and CWWS) and week (ag- 
Table 2. Composition of milk and Colby cheeses made with different methods of washing (means $\pm \mathrm{SD}$ )

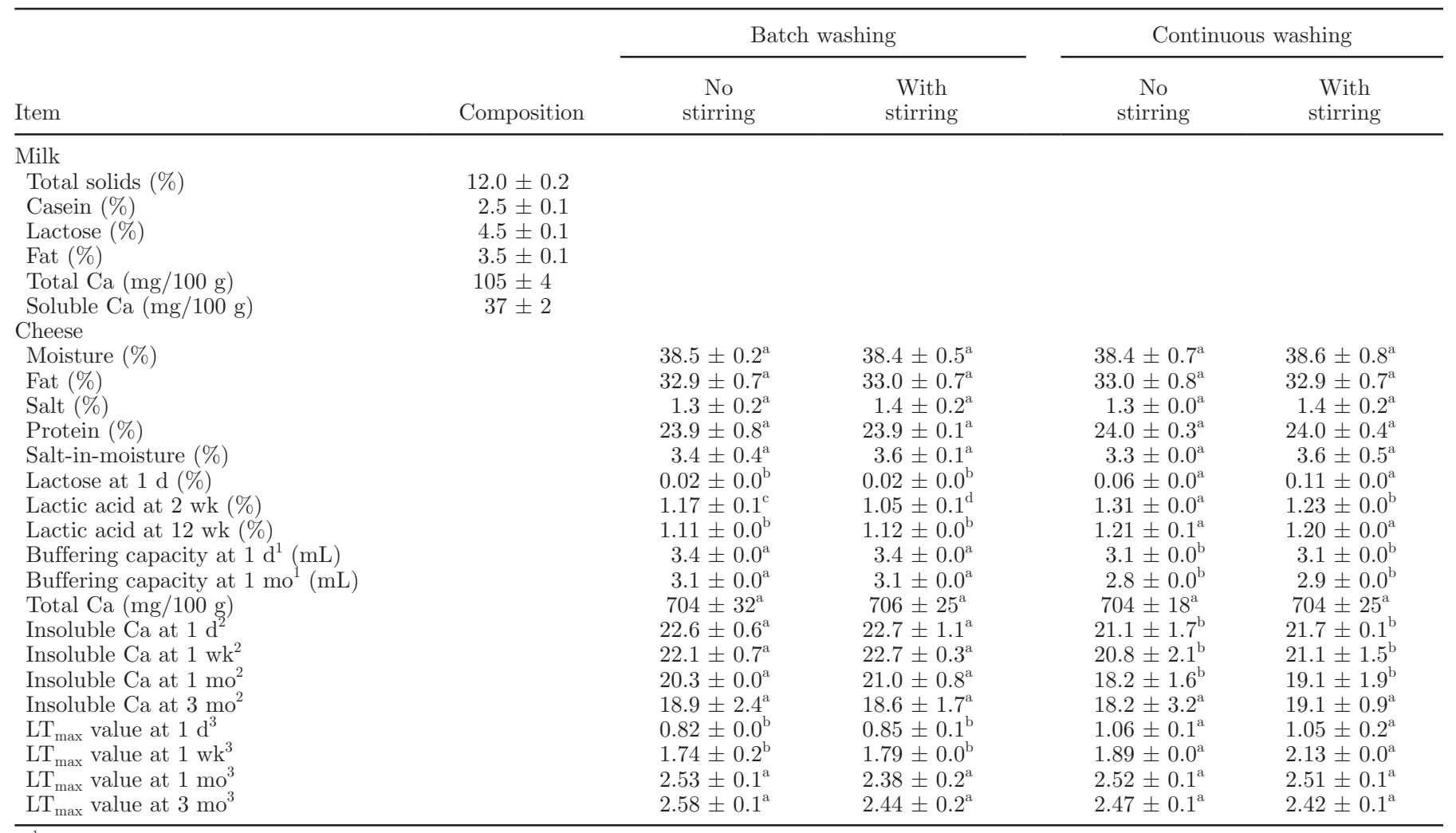

${ }^{\mathrm{a}-\mathrm{d}}$ Means with different letters in the same row indicate that values were significantly different $(P<0.05)$.

${ }^{1}$ The amount of $0.5 \mathrm{~N} \mathrm{HCl}$ solution required to titrate cheese homogenate $(8 \mathrm{~g}$ of cheese $/ 40 \mathrm{~g}$ of water) from its starting $\mathrm{pH}$ to $1.0 \mathrm{pH}$ unit lower than the initial $\mathrm{pH}$.

${ }^{2}$ Milligrams of insoluble $\mathrm{Ca} / \mathrm{g}$ of protein in cheese.

${ }^{3} \mathrm{LT}_{\max }$ is the maximum loss tangent during heating from small amplitude oscillatory rheology (SAOR) test.

ing time) on INSOL Ca content, rheological properties and $\mathrm{pH}$ 4.6-soluble nitrogen were evaluated using the Proc MIXED procedure for repeated measurement of the SAS software package. Effects included method, week, and method $\times$ week interactions. The least mean squares for cheese, nested within method, were used as random error terms in the test method. The Fisher protected least significant difference test was used to compare means and differences between means were considered to be significant at $P<0.05$. Pearson correlation coefficients were estimated between the various responses (i.e., INSOL Ca, $\mathrm{pH}$ 4.6-soluble nitrogen, rheological, and parameters).

\section{RESULTS AND DISCUSSION}

\section{Cheesemaking}

Similar $(P>0.05)$ first draining $\mathrm{pH}$ values of approximately 6.0 to 6.05 and 5.92 to 5.98 were obtained for BW and CW cheese, respectively (Table 1). The key manufacturing $\mathrm{pH}$ values were kept constant when the washing process was varied (Table 1 ). The second draining $\mathrm{pH}$ was also similar in all cheeses. The similar manufacturing $\mathrm{pH}$ values at the critical points during cheese making resulted in cheese having similar total Ca contents (Table 2). The amount of Ca retained after cheese making is very dependent on the $\mathrm{pH}$ at whey draining (Lucey and Fox, 1993).

\section{Chemical Composition of Cheese}

The moisture content of all cheeses (Table 2) was approximately 38 to $39 \%$, which is typical of Colby cheese (Fox and McSweeney, 2004). The moisture, fat, and protein contents of cheese were not significantly different (Table 2).

The residual (1-d) lactose contents of BW cheese $(0.02 \%)$ were significantly lower (Table 2$)$ than those of $\mathrm{CW}$ cheeses (0.06 to $0.11 \%$ ). The lactose level of all of these cheeses was much lower compared with the typical residual (1-d) lactose content $(0.4-0.8 \%)$ of 
Cheddar cheese (Fox and McSweeney, 2004). The use of higher salt levels in Cheddar cheese also slows the fermentation of lactose (Swearingen et al., 2004).

The lactic acid content of cheeses at 2 wk of ripening ranged from 1.05 to $1.31 \%$ (Table 2) and decreased in the following order; CWNS > CWWS > BWNS > BWWS. The higher lactic acid levels in CW cheeses (at 2 and 12 wk) were probably due to their higher initial residual lactose contents (Table 2). Fermentation of the residual lactose in cheese during ripening increases the lactic acid levels (Huffman and Kristoffersen, 1984; Shakeel-Ur-Rehman et al., 2004).

\section{Cheese $\mathrm{pH}$}

The $\mathrm{pH}$ of all cheeses at $1 \mathrm{~d}$ was significantly lower $(P<0.05)$ compared with the cheese $\mathrm{pH}$ values at 3 mo (Figure 1 ). The $\mathrm{pH}$ values at $1 \mathrm{~d}$ for all cheeses were not significantly different. Batch washing with stirring cheese had a significantly higher cheese $\mathrm{pH}$ compared with BWNS cheese at the 1-wk and 1-mo ripening time (Figure 1). An increase in cheese $\mathrm{pH}$ is due to the reduction of INSOL Ca. When Ca is solubilized, phosphate groups are released from colloidal $\mathrm{Ca}$ phosphate and this phosphate combines with hydrogen ions decreasing the concentration of free hydrogen ions in cheese, which results in an increase in cheese $\mathrm{pH}$ (Hassan et al., 2004). An increase in cheese $\mathrm{pH}$ during ripening in cheeses with a curd washing or whey dilution step has been reported in other studies (Huffman and Kristoffersen, 1984; Shakeel-Ur-Rehman et al., 2004).

A higher buffering capacity was observed in BW cheeses compared with $\mathrm{CW}$ cheeses at both $1 \mathrm{~d}$ and 1 mo of ripening (Table 2) and this corresponded with higher levels of INSOL Ca in the BW cheeses.

\section{Ca Equilibrium in Cheese}

Total Ca content of cheese was about $704 \mathrm{mg} / 100 \mathrm{~g}$ of cheese, which is typical for Colby cheese (Johnson and Lucey, 2006). The total Ca contents (Table 2) of all of the cheeses were not significantly different, presumably due to use of similar draining $\mathrm{pH}$ values in all treatments. The initial (1-d) INSOL Ca content was significantly higher in BW cheeses than in CW cheeses (Table 2; Figure 2). It should be noted that this indicated that it was possible to vary the initial INSOL Ca content of cheese by adopting different washing methods, without changing the total Ca content of cheese (Table 2). After 1 mo of ripening, no significant difference was observed in the INSOL Ca content of all cheeses (Table 2).

A decrease in INSOL Ca content of all cheeses during ripening was observed, as measured by both acid-base titration and cheese juice methods (Figure 2). A sig- nificant decrease in the INSOL Ca content of Cheddar (Hassan et al., 2004; Lee et al., 2005; Lucey et al., 2005) and Colby (Lee et al., 2010) cheese during ripening has been reported.

The extent of the decrease in the INSOL Ca content (mg/100 $\mathrm{g}$ of protein in cheese) of the various types of cheeses during the first month of ripening was in the following order: CWNS > CWWS > BWNS > BWWS (Table 2). After $1 \mathrm{mo}$, the $\mathrm{CW}$ cheese did not show any further decrease in INSOL Ca content (Table 2), whereas BW cheeses continued to exhibit a decrease in the INSOL Ca content (1.4 and $2.4 \mathrm{mg} / 100 \mathrm{~g}$ of protein in cheese for BWNS and BWWS, respectively). This trend was observed with both juice and acid-base titration methods (Figure 2).

The significantly higher initial lactose content in CW cheeses and its subsequent fermentation to lactic acid during the first month of ripening (Table 2) contributed to its greater loss of INSOL Ca compared with BW cheeses (Lee et al., 2005). After 1 mo, a stable pseudo-equilibrium was probably reached for the CW cheese (Lee et al., 2005; O'Mahony et al., 2006) as little further decrease in INSOL Ca content took place. The initial decrease in the INSOL Ca content in BW cheese was slower than in CW cheese probably due to the low levels of lactic acid (Table 2), but the decrease in INSOL Ca content in BW cheeses continued during the 3 mo of ripening. The BW cheeses appeared to have a lower concentration of soluble components, as indicated by the lower initial lactose content of the curd, probably due to a more effective washing process compared

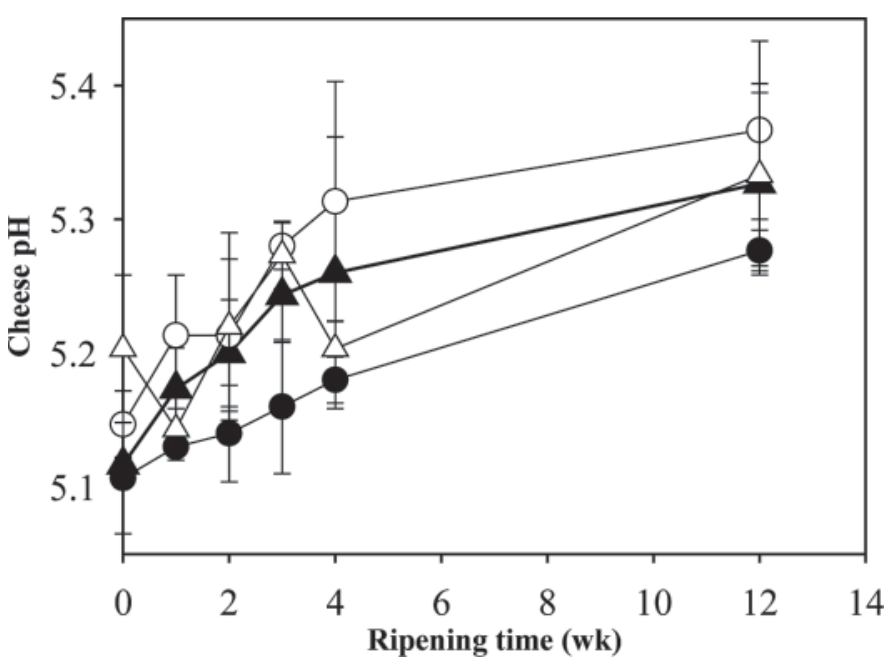

Figure 1. Changes in cheese $\mathrm{pH}$ for batch washing with no stirring (BWNS; $\bullet$ ), batch washing with stirring (BWWS; O), continuous washing with no stirring (CWNS; $\mathbf{\Delta}$ ), and continuous washing with stirring (CWWS; $\Delta$ ) as a function of ripening time. The data represent the means $(\mathrm{n}=3)$, whereas the error bars represent the SD for each time point. 
Table 3. Pearson correlation coefficients between different ripening parameters ${ }^{1}$ of cheese made with the different washing methods

\begin{tabular}{|c|c|c|c|c|}
\hline Item & $\begin{array}{l}\text { Cheese } \\
\text { pH }\end{array}$ & $\mathrm{LT}_{\max }$ & $\begin{array}{l}\text { Temperature } \\
\text { at } \mathrm{LT}_{\max }\end{array}$ & $\begin{array}{l}\mathrm{G}^{\prime} \text { value } \\
\text { at } 40^{\circ} \mathrm{C}\end{array}$ \\
\hline $\begin{array}{l}\text { INSOL Ca } \\
\text { Cheese pH } \\
\mathrm{LT}_{\max }\end{array}$ & $-0.56^{* * * *}$ & $\begin{array}{r}-0.76^{* * * *} \\
0.60^{* * * *}\end{array}$ & $\begin{array}{r}0.62^{* * * *} \\
-0.60^{* * * *} \\
-0.44^{* * * *}\end{array}$ & $\begin{array}{r}0.67^{* * * * *} \\
-0.51^{* * * *} \\
-0.79^{* * * *}\end{array}$ \\
\hline
\end{tabular}

${ }^{1}$ INSOL $\mathrm{Ca}=$ percentage of insoluble $\mathrm{Ca}$ as a percentage of total $\mathrm{Ca} ; \mathrm{LT}_{\max }=$ maximum loss tangent; $\mathrm{G}^{\prime}=$ storage modulus.

$* * * * P<0.0001$.

with that for the CW cheeses. A lower initial soluble Ca concentration in cheese sera made from BW could explain why we observed the slow ongoing solubilization of INSOL Ca during ripening for this type of cheese.

Significant correlations were observed between ripening parameters, although the strength of these relationships was not very high $(r<0.80)$. Cheese $\mathrm{pH}$ values and INSOL Ca contents of cheese during aging were significantly negatively correlated $(P<0.0001, r=$

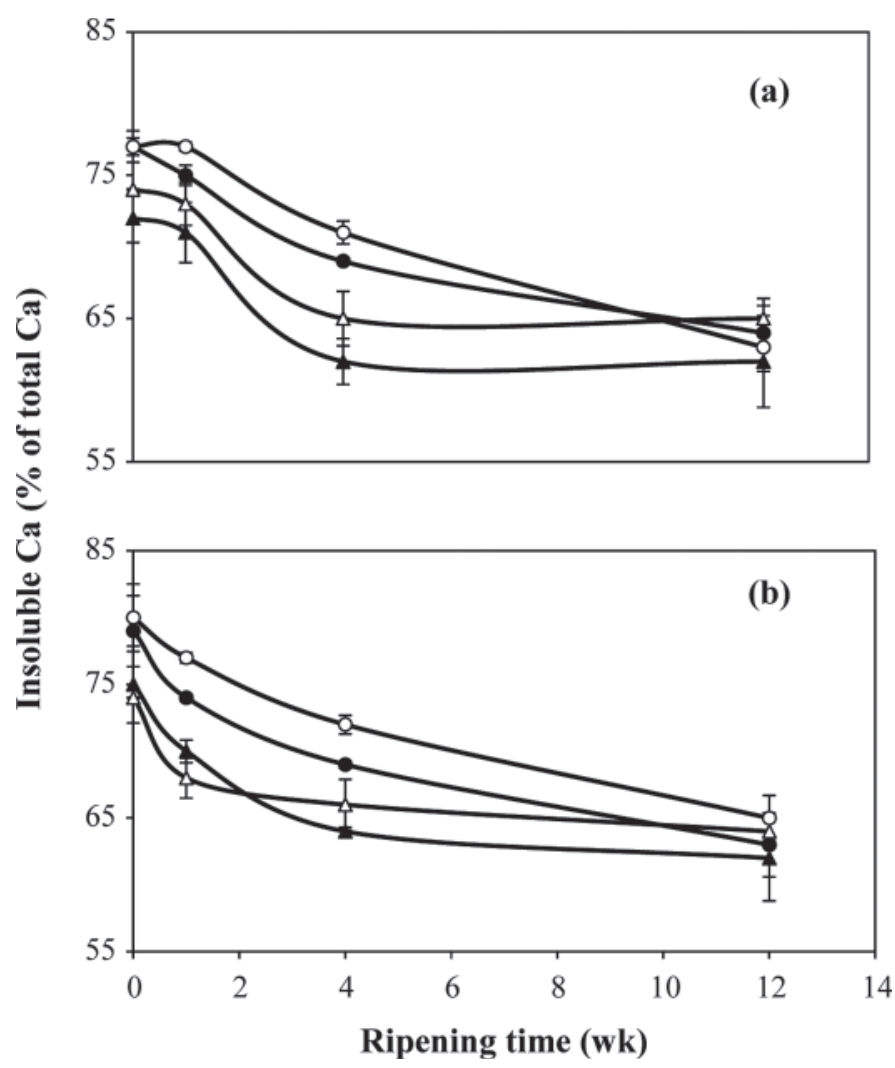

Figure 2. Changes in the percentage of insoluble Ca content (percentage of total $\mathrm{Ca}$ in cheese) for batch washing with no stirring (BWNS; $\bullet$ ), batch washing with stirring (BWWS, O), continuous washing with no stirring (CWNS; $\Delta$ ), and continuous washing with stirring (CWWS; $\Delta$ ) as a function of ripening time by cheese juice (a) and by acid-base titration (b) methods. The data represent the means $(n=3)$, whereas the error bars represent the SD for each time point.
-0.56; Table 3). Lower $\mathrm{pH}$ values (higher acid) probably help to solubilize the INSOL Ca in cheese.

The INSOL Ca content of cheese during ripening was significantly affected $(P<0.001)$ by washing method (i.e., BW or $\mathrm{CW}$ ) and ripening time (Table 4). The stirring process did not significantly affect the INSOL $\mathrm{Ca}$ content of cheese. For both the batch and the $\mathrm{CW}$ approaches, only minor differences existed in the lactic acid/lactose or INSOL Ca contents of cheeses made with stirring or without stirring (Table 2).

\section{Rheological Properties of Cheese}

The $\mathrm{G}^{\prime}$ values of cheese at $5^{\circ} \mathrm{C}$ during ripening were considerably higher than the values at $40^{\circ} \mathrm{C}$, which were higher than those at $80^{\circ} \mathrm{C}$ (Figure 3). A similar trend was reported by Lucey et al. (2005) for Cheddar cheese. The initial $\mathrm{G}^{\prime}$ of cheeses at $5^{\circ} \mathrm{C}$ at $1 \mathrm{~d}$ was in the range of 260 to $350 \mathrm{kPa}$ (Figure 3a). The $\mathrm{G}^{\prime}$ values at $5^{\circ} \mathrm{C}$ for the CWNS cheese was lower compared with the other cheeses (Figure 3a). The $\mathrm{G}^{\prime}$ values at $1 \mathrm{~d}$ and $1 \mathrm{wk}$ for $\mathrm{BW}$ cheeses measured at $80^{\circ} \mathrm{C}$ tended to be higher than those for the $\mathrm{CW}$ cheeses (Figure 3c). It should be noted that BW cheese had a significantly higher INSOL Ca content at $1 \mathrm{~d}$ and 1 wk compared with CW cheese (Table 2). The INSOL Ca content has been related to the $\mathrm{G}^{\prime}$ value of cheese measured at high temperatures because INSOL Ca interactions are heat stable, whereas most other interactions (e.g., hydrogen bonds) may weaken with increasing temperature (O'Mahony et al., 2006). At ripening periods longer than $1 \mathrm{wk}$, the $\mathrm{G}^{\prime}$ values at 5,40 , and $80^{\circ} \mathrm{C}$ were similar between treatments (Figure 3). The $\mathrm{G}^{\prime}$ values at $40^{\circ} \mathrm{C}$ and INSOL Ca contents were significantly positively correlated $(P<0.0001 ;$ Table 3$)$. A significant negative correlation $(P<0.0001)$ existed between the $\mathrm{G}^{\prime}$ values at $40^{\circ} \mathrm{C}$ and $\mathrm{pH}$ values, probably due to effect of $\mathrm{pH}$ on the INSOL Ca content.

The initial (1-d) maximum LT ( $\left.\mathbf{L T}_{\max }\right)$ values were in the range of 0.8 to 1.1 and an increase in the $\mathrm{LT}_{\max }$ values occurred in all cheeses during the first $4 \mathrm{wk}$ (Table 2 ). During ripening, an increase in the $\mathrm{LT}_{\max }$ value of cheese with $\mathrm{pH}$ values $>5.0$ has been reported in other 
Table 4. Mean squares, probabilities, and df for factors that may influence the insoluble (INSOL) Ca content ${ }^{1}$ of Colby cheese

\begin{tabular}{lccc}
\hline Factor & df & Mean squares & $P$-value \\
\hline Washing method $^{2}$ & 1 & 70.84 & $0.0008^{*}$ \\
Stirring method $^{3}$ & 1 & 10.11 & 0.0690 \\
Error & 7 & 2.19 & $<0.0001^{*}$ \\
Week $^{4}$ & 3 & 257.60 & $0.04^{*}$ \\
Washing method $\times$ week & 3 & 11.23 & 0.93 \\
Stirring method $\times$ week & 3 & 0.46 & 0.93 \\
Washing method $\times$ week $\times$ stirring method & 3 & 0.50 & \\
Error & 19 & 3.34 & \\
$\mathrm{R}^{2}$ & 0.95 & & \\
\hline
\end{tabular}

${ }^{1}$ Insoluble Ca content as a percentage of total $\mathrm{Ca}$ in cheese determined by the cheese juice method.

${ }^{2}$ Washing methods used were batch washing and continuous washing.

${ }^{3}$ Stirring methods during cheese manufacture were stirring or no stirring.

${ }^{4}$ Cheese-ripening time.

$* P<0.05$.

studies (Lee et al., 2005; Lucey et al., 2005). During ripening at the 1-d and 1-wk time points, significantly higher $\mathrm{LT}_{\max }$ values were observed for $\mathrm{CW}$ cheeses compared with BW cheese (Table 2). No differences existed in $\mathrm{LT}_{\max }$ values between cheeses manufactured with or without stirring (Table 2). Cheese $\mathrm{pH}$ was significantly positively correlated with $\mathrm{LT}_{\max }$ value $(P<0.0001$; Table 3). Significantly negative correlations were observed between the INSOL Ca content of cheese and

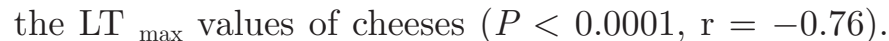
Higher $\mathrm{LT}_{\max }$ values with lower INSOL Ca contents of Cheddar cheese have been previously reported (Lucey et al., 2005; O'Mahony et al., 2006), suggesting that the loss of INSOL Ca facilitates more meltable cheese (Lucey et al., 2003).

The temperature of the $\mathrm{LT}_{\max }$ generally decreased during ripening for all cheeses, apart from a slight increase between $1 \mathrm{~d}$ and $1 \mathrm{wk}$ (Figure 4); the small increase in the temperature of the $\mathrm{LT}_{\max }$ value (i.e., more thermal energy required for cheese to melt/flow) during the first week may have been due to a combination of an increase in cheese $\mathrm{pH}$ and small increase in the $\mathrm{G}^{\prime}$ values at $5^{\circ} \mathrm{C}$ in this period. A decrease in the temperature of the $\mathrm{LT}_{\max }$ has been observed in other cheeses during ripening (Lee et al., 2005; Lucey et al., 2005). The decrease in the temperature of the $\mathrm{LT}_{\max }$ during most of the ripening period could be related to the combined effect of the ongoing loss of INSOL Ca cross-linking between $\mathrm{CN}$ and proteolysis, which makes it easier for cheese to melt when heated.

\section{Proteolytic Activity (Level of $\mathrm{pH}$ 4.6-Soluble Nitrogen)}

A continuous increase occurred in the level of $\mathrm{pH}$ 4.6-soluble nitrogen with age in all cheeses (Figure 5); no significant differences were observed in the levels of
$\mathrm{pH}$ 4.6-soluble nitrogen in cheeses at $1 \mathrm{~d}, 1 \mathrm{wk}$, and 3 mo. This suggests that different curd-washing methods did not affect proteolysis during cheese ripening. Thus, $\mathrm{pH}$ 4.6-soluble nitrogen was not influenced by the differences in the INSOL Ca content of our experimental cheeses, which is in contrast to other studies that observed higher levels of proteolysis in cheeses that had greater acid development (Watkinson et al., 2001; Lee et al., 2005). The increase in $\mathrm{pH}$ observed in Colby cheese was in contrast to these previous studies and higher $\mathrm{pH}$ values may have favored plasmin activity but decreased residual rennet activity.

O'Mahony et al. (2005) reported that the decrease in hardness of Cheddar cheese during first 3 wk of ripening was more highly correlated with the level of INSOL $\mathrm{Ca}$ than the level of $\mathrm{pH}-4.6$ soluble nitrogen in cheese where residual coagulant activity was inhibited by the addition of pepstatin (a potent competitive inhibitor of aspartyl proteases). O'Mahony et al. (2005) proposed that the initial softening of texture in Cheddar cheese was largely due to the solubilization of INSOL Ca.

Therefore, the initial differences in melting (e.g., higher $\mathrm{LT}_{\max }$ values) properties of cheese from the different washing techniques was likely due to the differences in the levels of INSOL Ca content in these cheeses (Table 2), rather than the levels of $\mathrm{pH}$ 4.6-soluble nitrogen because no significant differences in proteolysis were observed between treatments (Figure 5). Insoluble $\mathrm{Ca}$ is a key cross-linking material between CN (Horne, 1998) and a lower INSOL Ca content of cheese can give softer and more meltable cheese (Lucey and Fox, 1993) unless the $\mathrm{pH}$ of cheese is very low $(\mathrm{pH}<4.9$; Lee et al., 2005). The higher initial INSOL Ca level in BW cheese compared with $\mathrm{CW}$ cheese may result in greater protein-Ca interactions compared with those in $\mathrm{CW}$ cheese and limit the ability of $\mathrm{CN}-\mathrm{CN}$ interactions to relax at high temperatures and, thus, retard melt ( $\mathrm{Lu}-$ 

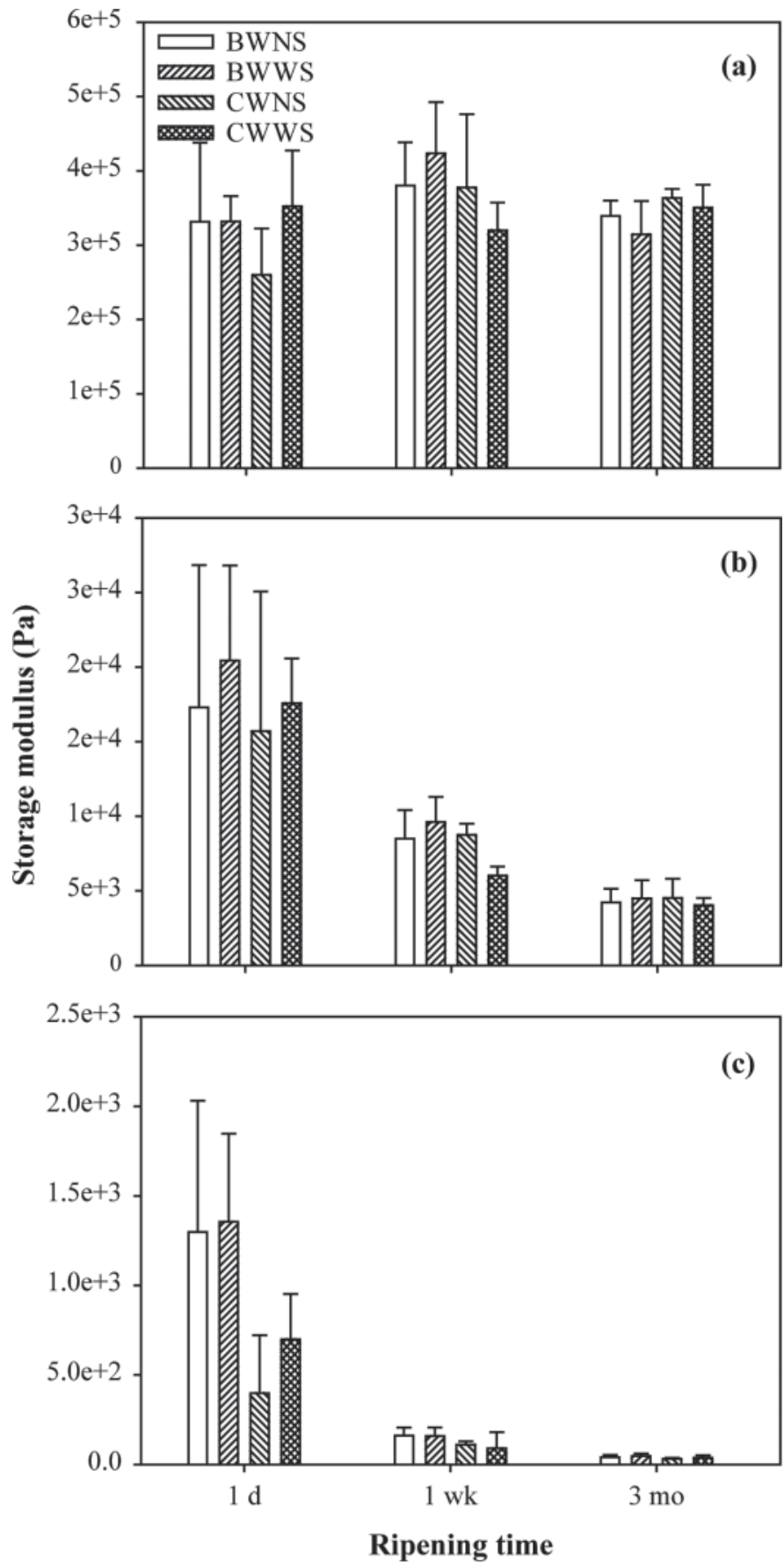

Figure 3. Changes in storage modulus $\left(\mathrm{G}^{\prime}\right)$ at $5(\mathrm{a}), 40(\mathrm{~b})$, and $80^{\circ} \mathrm{C}$ (c) as a function of ripening time for cheese tested at $1 \mathrm{~d}, 1 \mathrm{wk}$, and 3 mo using the small amplitude oscillatory rheology method. The data represent the means $(\mathrm{n}=3)$, whereas the error bars represent the SD for each time point. BWNS = batch washing with no stirring; BWWS = batch washing with stirring; CWNS = continuous washing with no stirring; CWWS = continuous washing with stirring.

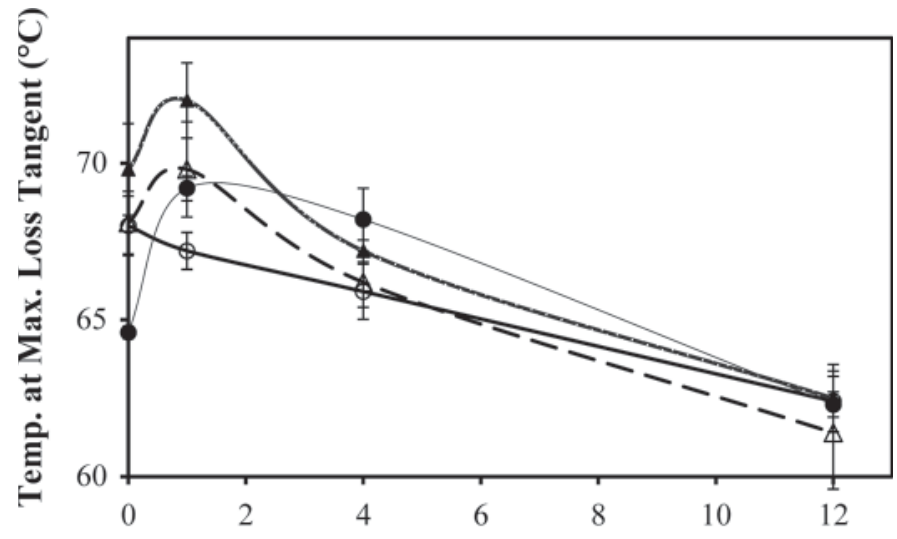

Ripening time (wk)

Figure 4. Changes in the temperature at maximum loss tangent from the small amplitude oscillatory rheology test for batch washing with no stirring (BWNS; $\bullet$ ), batch washing with stirring (BWWS; O), continuous washing with no stirring (CWNS; $\mathbf{\Delta}$ ), and continuous washing with stirring (CWWS; $\Delta$ ) as a function of ripening time. The data represent the means $(n=3)$, whereas the error bars represent the $\mathrm{SD}$ for each time point.

cey et al., 2005). The $\mathrm{G}^{\prime}$ value at $40^{\circ} \mathrm{C}$ was significantly correlated with INSOL Ca content of cheese, indicating that cheese stiffness $\left(\mathrm{G}^{\prime}\right)$ was related to INSOL Ca cross-linking.

\section{CONCLUSIONS}

Different curd-washing methods altered the levels of residual lactose, lactic acid, and INSOL Ca in Colby cheese. Cheeses made with the CW method had higher residual lactose and lactic acid contents compared with cheeses made with BW. The total Ca contents of

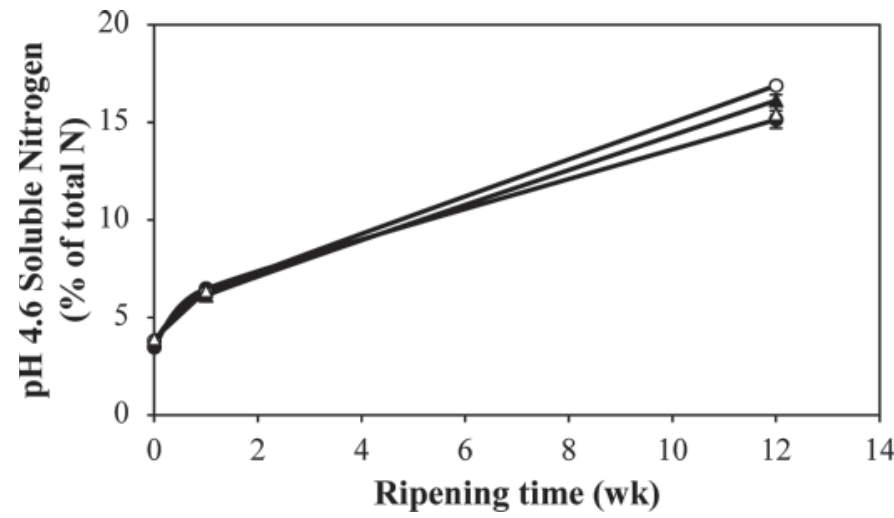

Figure 5. Changes in the $\mathrm{pH}$ 4.6-soluble nitrogen as percentage of total nitrogen for batch washing with no stirring (BWNS; $\bullet$ ), batch washing with stirring (BWWS; O), continuous washing with no stirring (CWNS; $\mathbf{\Delta}$ ), and continuous washing with stirring (CWWS; $\Delta$ ) as a function of ripening time. The data represent means $(\mathrm{n}=3)$, whereas the error bars represent the SD for each time point.

Journal of Dairy Science Vol. 94 No. 6, 2011 
cheeses made with different washing methods were not significantly different; the total Ca content of cheese is largely dictated by the $\mathrm{pH}$ values at renneting and at whey drainage and in our cheesemaking experiments, all of the key manufacturing $\mathrm{pH}$ values were similar. The INSOL Ca content of cheese was influenced by the lactic acid levels in cheese, which were altered by the method of curd washing. The $\mathrm{pH}$ of all cheeses increased during ripening, probably due to the ongoing solubilization of INSOL Ca. No significant differences in overall proteolytic activity during ripening were observed in cheeses made from the different washing methods. When heated, cheeses made with the CW method were softer and more meltable, presumably due to their lower INSOL Ca content, compared with cheeses made with BW. In conclusion, the method used to wash curd can be used to modify the chemical and rheological properties of cheese. Washing method is another factor for Colby cheese makers to consider if they wish to alter the textural properties of their cheese.

\section{ACKNOWLEDGMENTS}

The authors appreciate the funding of Dairy Management Inc., as Dairy Research Institute (Rosemont, IL) and the Wisconsin Milk Marketing Board (Madison, WI). The authors thank Bill Hoesly of the Wisconsin Center for Dairy Research (Madison) for cheese making. The authors thank Juan Romero and Bill Tricomi of the Wisconsin Center for Dairy Research for technical support.

\section{REFERENCES}

Fox, P. F., and P. L. H. McSweeney. 2004. Cheese: An overview. Pages 1-18 in Cheese Chemistry, Physics and Microbiology. 3rd ed. Vol. 1: General Aspects. P. F. Fox, P. L. H. McSweeney, T. M. Cogan, and T. P. Guinee, ed. Elsevier Academic Press, London, UK.

Hassan, A., M. E. Johnson, and J. A. Lucey. 2004. Changes in the proportions of soluble and insoluble calcium during the ripening of Cheddar cheese. J. Dairy Sci. 87:854-862.

Horne, D. S. 1998. Casein interactions: Casting light on the black boxes, the structure in dairy products. Int. Dairy J. 8:171-177.

Huffman, L. M., and T. Kristoffersen. 1984. Role of lactose in Cheddar cheese manufacturing and ripening. N.Z. J. Dairy Sci. Tech. 19:151-162.

IDF. 1993. Milk and milk products-Determination of lactose content-Enzyme methods. 285:1993. International Dairy Federation, Brussels, Belgium.

Johnson, M. E., and J. A. Lucey. 2006. Calcium: A key factor in controlling cheese functionality. Aust. J. Dairy Technol. 61:147-153.
Kuchroo, C. N., and P. F. Fox. 1982. Soluble nitrogen in Cheddar cheese: Comparison of extraction procedures. Milchwissenschaft $37: 331-335$.

Lee, M.-R., M. E. Johnson, S. Govindasamy-Lucey, J. J. Jaeggi, and J. A. Lucey. 2010. Insoluble calcium content and rheological properties of Colby cheese during ripening. J. Dairy Sci. 93:1844-1853.

Lee, M.-R., M. E. Johnson, and J. A. Lucey. 2005. Impact of modifications in acid development on the insoluble calcium content and rheological properties of Cheddar cheese. J. Dairy Sci. 88:37983809 .

Lolkema, H. 1994. Cheese yield used as an instrument for process control-Experience in Friesland, the Netherlands. Pages 156-197 in Factors Affecting the Yield of Cheese. Special Issue No. 9301. International Dairy Federation, Brussels, Belgium.

Lucey, J. A., and P. F. Fox. 1993. Importance of calcium and phosphate in cheese manufacture: A review. J. Dairy Sci. 76:1714-1724.

Lucey, J. A., M. E. Johnson, and D. S. Horne. 2003. Perspectives on the basis of the rheology and texture properties of cheese. J. Dairy Sci. 86:2725-2743.

Lucey, J. A., R. Mishra, A. Hassan, and M. E. Johnson. 2005. Rheological and calcium equilibrium changes during ripening of Cheddar cheese. Int. Dairy J. 15:645-653.

Marshall, R. T. 1992. Standard Methods for the Examination of Dairy Products. 16th ed. American Public Health Association, Washington, DC.

O'Mahony, J. A., J. A. Lucey, and P. L. H. McSweeney. 2005. Chymosin-mediated proteolysis, calcium solubilization, and texture development during the ripening of Cheddar cheese. J. Dairy Sci. 88:3101-3114.

O'Mahony, J. A., P. L. H. McSweeney, and J. A. Lucey. 2006. A model system for studying the effects of colloidal calcium phosphate concentration on the rheological properties of Cheddar cheese. J. Dairy Sci. 89:892-904.

Park, Y. W. 2000. Comparison of mineral and cholesterol composition of different commercial goat milk products manufactured in USA. Small Rumin. Res. 37:115-124.

Severn, D. J., M. E. Johnson, and N. F. Olson. 1986. Determination of lactic acid in Cheddar cheese and calcium lactate crystals. J. Dairy Sci. 69:2027-2030.

Shakeel-Ur-Rehman, D. Waldron, and P. F. Fox. 2004. Effect of modifying lactose concentration in cheese curd on proteolysis and in quality of Cheddar cheese. Int. Dairy J. 14:591-597.

Swearingen, P. A., D. E. Adams, and T. L. Lensmire. 2004. Factors affecting calcium lactate and whey expulsion defects in Cheddar cheese. J. Dairy Sci. 87:574-582.

Van den Berg, V. G., and E. De Vries. 1974. Der Zusammenhang zwischen den Faktoren, die den $\mathrm{pH}$ von Käse beeinflussen. Milchwissenschaft 29:214-218.

Van Slyke, L. L., and W. V. Price. 1936. Cheese; A Treatise on the Manufacture of American Cheddar Cheese and Some Other Varieties. Orange Judd Publ. Co., Inc., New York, NY.

Walstra, P., T. J. Geurts, A. Noomen, A. Jellema, and M. A. J. S. van Boekel. 1999. Dairy Technology: Principles of Milk Properties and Processes. Marcel Dekker, Inc., New York, NY.

Watkinson, P., C. Coker, R. Crawford, C. Dodds, K. Johnston, A. McKenna, and N. White. 2001. Effect of cheese pH and ripening time on model cheese textural properties and proteolysis. Int. Dairy J. 11:455-464.

Wilson, H. L., and G. W. Reinbold. 1965. American Cheese Varieties. Pfizer Cheese Monograph Series. Vol. 2. Pfizer and Co., Inc. New York, NY. 